\title{
DITRICHOPSIS CLAUSA BROTH. (DITRICHACEAE, MUSCI), A NEW SPECIES FOR RUSSIA
}

\section{DITRICHOPSIS CLAUSA BROTH. (DITRICHACEAE, MUSCI) - НОВЫЙ ВИД ДЛЯ РОССИИ}

\author{
OLGA M. AFONINA ${ }^{1} \&$ ELENA A. IGNATOVA ${ }^{2}$ \\ ОЛЬГА М. АФОНИНА ${ }^{1}$, ЕЛЕНА А. ИГНАТОВА ${ }^{2}$
}

Abstract

\begin{abstract}
Ditrichopsis clausa Broth. was collected in ZabaikalskyTerrotory (South Siberia). It is newly recorded for Russia. It was previously known from two localities in China (Yunnan and Sichuan) and from northeastern India (Sikkim). Description based on specimen from Russia, illustration and distribution map of this rare East Asian species are provided.
\end{abstract}

Резюме

В Забайкальском крае (Южная Сибирь) обнаружен новый вид для флоры мхов России Ditrichopsis clausa Broth. Ранее он был известен из двух местонахождений в Китае (Юньнань и Сычуань) и на северо-западе Индии (Сикким). Приводится описание этого редкого восточноазиатского вида на основании собранного материала, его рисунок и карта распространения.

KEYWORDS: Bryophyta, Ditrichopsis, Zabaikalsky Territory, Siberia, Russia.

The genus Ditrichopsis was established in 1924 by V.F. Brotherus to accomodate a newly described species, D. gymnostoma Broth. Five years later, a second species, D. clausa Broth., was added. For a long time, only single records of each species from China were know. In 2010, a third species of the genus, D. baicalense Ignatova \& Afonina was described from the Republic of Buryatia, Transbaikalia, Russia (Ignatova \& Afonina, 2010). Shortly after its description, this species was also found in Zabaikalsky Territory (Afonina et al, 2012) and in Krasnoyarsk Territory, Taimyr Autonomous District (Fedosov, 2012). In 2011, in a course of bryophyte flora exploration in Sokhondinsky Nature Reserve (Zabaikalsky Territory) Yu.S. Mamontov and the senior author collected simultaneously a plant which was later identified as D. clausa. It is newly recorded for Russia. This finding extends considerably a known distribution range of the species.

Ditrichopsis clausa Broth., Musci. Symb. Sin.: 147. 1929.

Fig. 1.

Plants small, growing as individual shoots among other bryophytes, green or yellowish-green in upper part, light brownish below, slightly glossy. Stems 2.5-4.0 mm, erect, simple, with well-developed central strand, cortical cells in 1-2 layers, with moderately thickened walls. Leaves erect or flexuose when wet and dry, occasionally slightly secund, $1.5-2.0 \times 0.2-0.3 \mathrm{~mm}$, from long ovate base rather suddenly narrowed into long triangular acumen of the same length as base or slightly longer, concave, with flat margins, entire or finely crenulate distally; costa not sharply delimited from lamina, rather wide, ca. 1/ $5-1 / 3$ the leaf base, gradually widening distally to the constriction of leaf from base to acumen, almost filling the acumen, in transverse section with one row of guide cells exposed on adaxial surface of costa or with an additional row of ventral epidermal cells, dorsal stereid band of 1-2 rows of thick-walled cells and \pm differentiated dorsal epidermis, cells on adaxial surface of costa rectangular, 45-80×9-14 $\mu \mathrm{m}$, cells on abaxial surface rectangular to linear, narrow, 20-35 $\times 4-6 \mu \mathrm{m}$; margins plane or widely recurved on one side, entire or with few denticulations at shoulders; lamina unistratose or with few bistratose strips near costa, at base of acumen 1-2 cells wide, upper laminal cells rectangular, narrow, 25-55×3.0-5.0 $\mu \mathrm{m}$; basal laminal cells rectangular, 30-40(-50) $\times 10-15 \mu \mathrm{m}$, with thin, non-porose walls, basal marginal cells not differentiated. Dioicous. Perichaetial leaves similar to stem leaves, ca. 2-2.5 mm long, with long acumen. Seta yellowish-green to light brownish, 1.5-2.5 mm, straight or cygneous. Capsule cleistocarpous, light brown, oval-cylindrical, $0.7-1.0 \times 0.3-0.5 \mathrm{~mm}$, abruptly contracted to straight or oblique beak ca. $0.3 \mathrm{~mm}$ long; exothecial cells rectangular, thin-walled. Spores 20-25(-30) $\mu \mathrm{m}$, finely papillose. Calyptra not observed.

1 - V.L. Komarov Botanical Institute Rus. Acad. Sci., Prof. Popov Str., 2, St. Petersburg, 197376 Russia - Россия 197376, г. Санкт-Петербург, ул. проф. Попова, д. 2, Ботанический институт им. В.Л. Комарова PAH; e-mail: stereodon@yandex.ru

2 - Moscow State University, Biological Faculty, Geobotany Dept., Moscow 119234 Russia - Россия 119234, Москва, Московский университет, Биологический факультет, каф. геоботаники; e-mail: arctoa@list.ru 

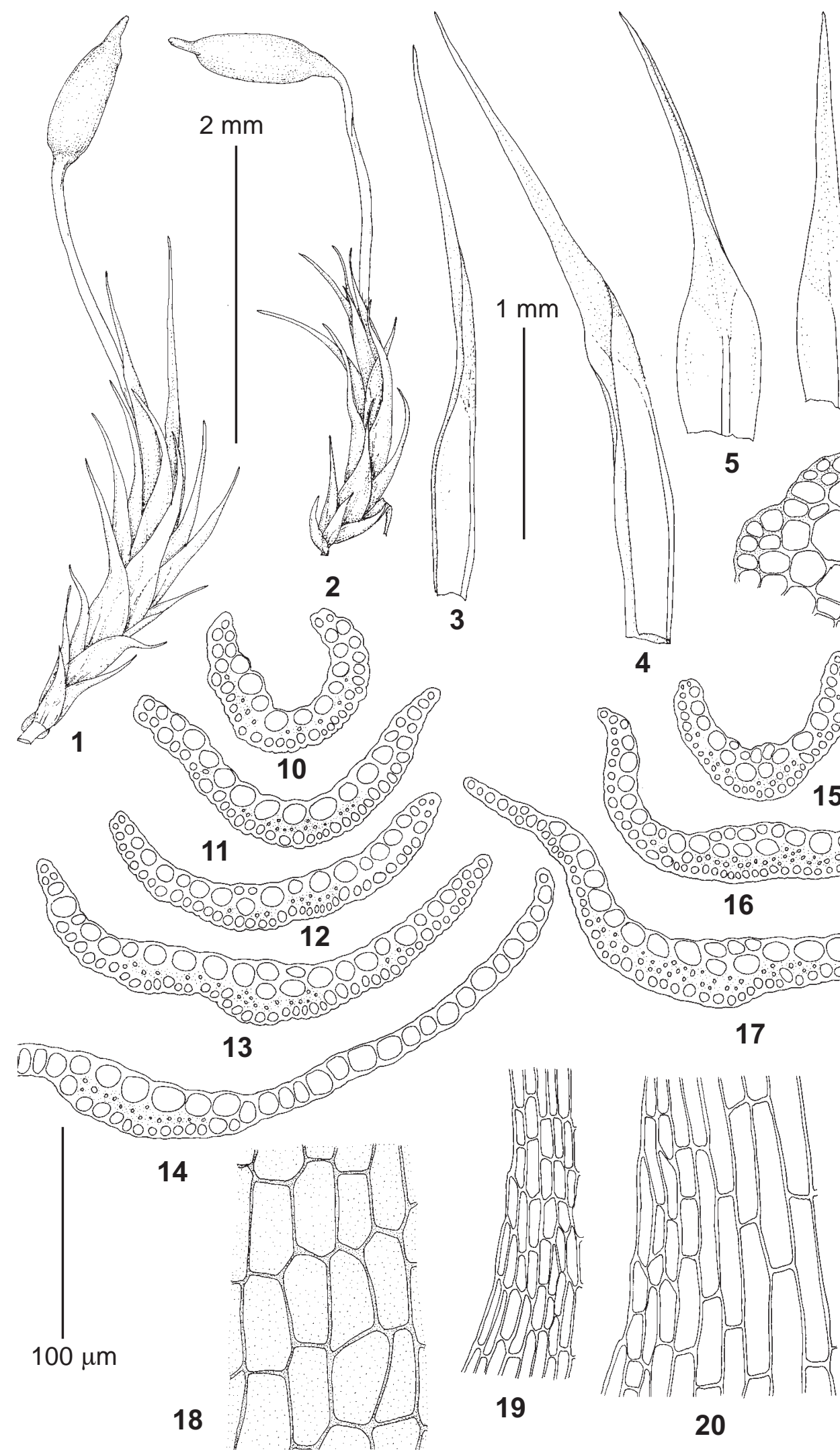

Fig. 1. Ditrichopsis clausa Broth. (from: Russia, Zabaikalsky Territory, Sokhondinsky Reserve, Afonina \#4511, LE): 1 - habit, wet; 2 - habit, dry; 3-4 - perichaetial leaves; 5-7 - leaves; 8 - upper laminal cells; 9 - stem transverse section; 10-17 - leaf transverse sections; 18 - exothecial cells; 19 - median laminal cells, abaxial side; 20 - median laminal cells, adaxial side; 21 - basal laminal cells. Scale bars: $2 \mathrm{~mm}$ for 1-2; $1 \mathrm{~mm}$ for 3-7; $100 \mu \mathrm{m}$ for $8-21$.
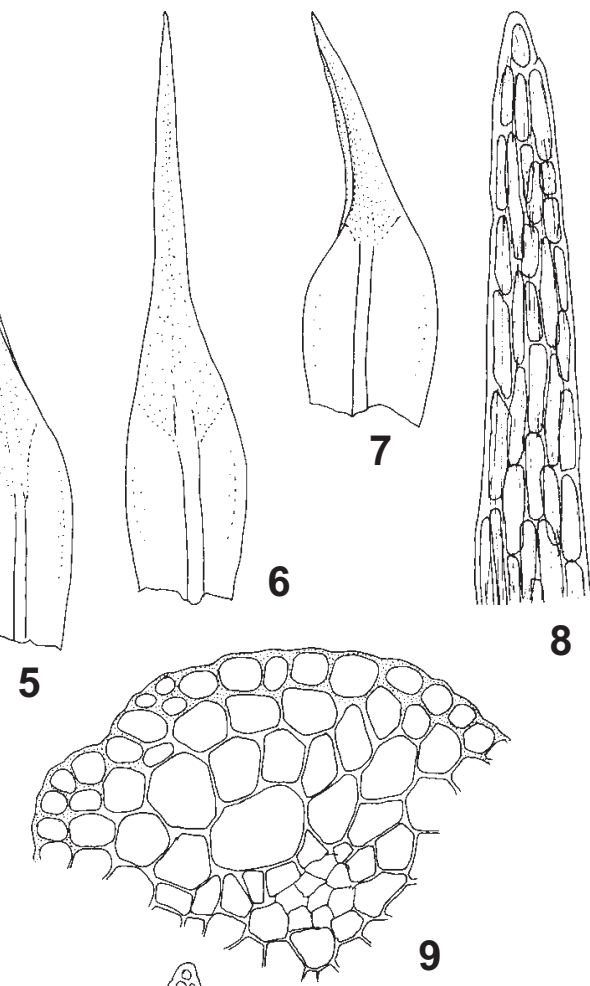

8 


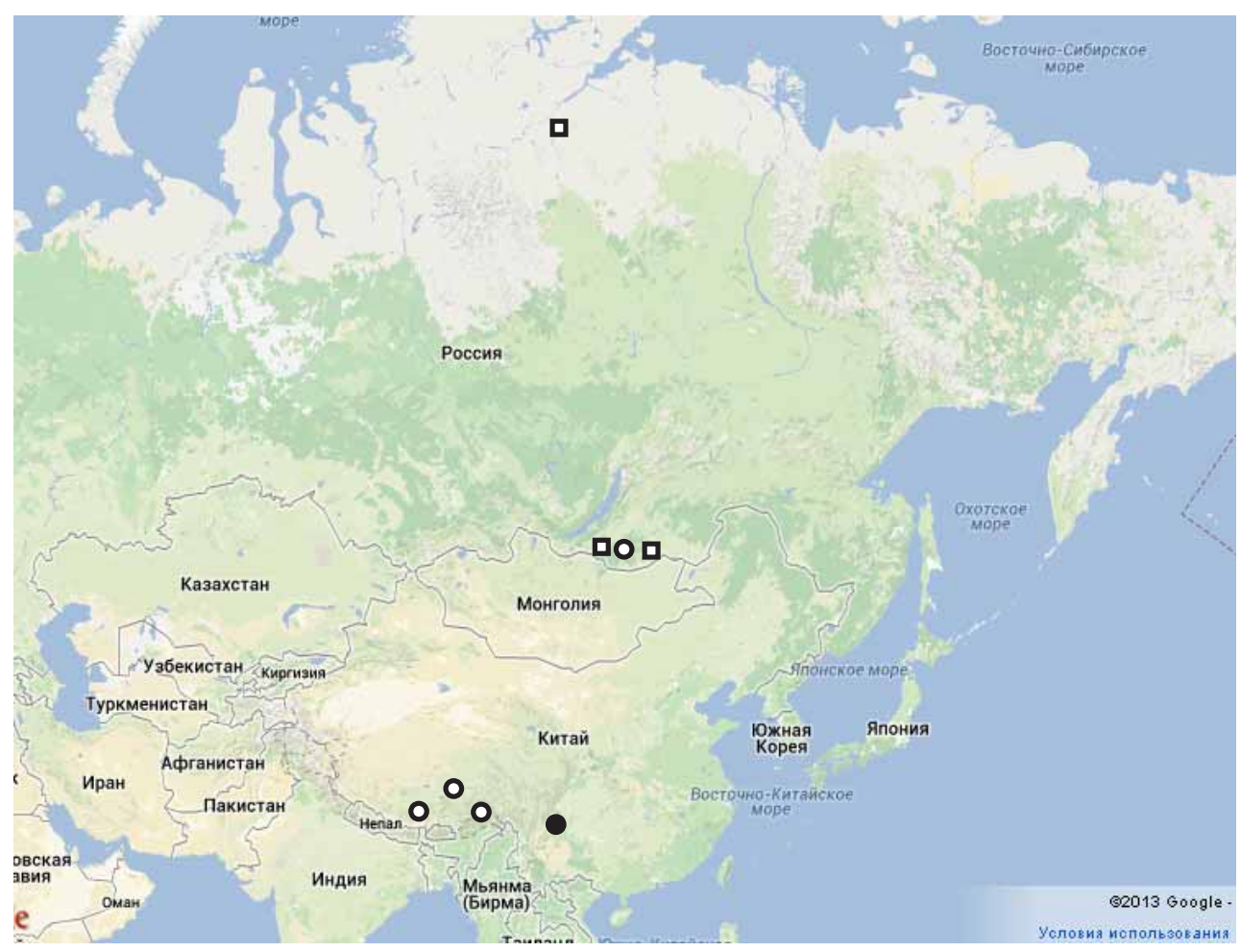

Fig. 2. World distribution of all three species of the genus Ditrichopsis: D. clausa Broth. is shown by open circles, D. baicalensis Ignatova \& Afonina by open squares and D. gymnostoma Broth. by solid circle.

Differentiation. Ditrichopsis clausa can be easily distinguished from other Ditrichopsis species by cleistocarpous capsule vs. stegocarpous and gymnostomous one in D. gymnostoma and D. baicalense. Leaves of D. clausa are longer than those of $D$. baicalense (1.5-3.5 mm vs. $1.0-1.3 \mathrm{~mm})$, but at the same time slightly narrower $(0.25-$ $0.4 \mathrm{~mm}$ vs. $0.3-0.5 \mathrm{~mm}$ ). These species also differ in spore size ( $25 \mu \mathrm{m}$ in D. clausa vs. $15-18 \mu \mathrm{m}$ in D. baicalense). For a comparison of three species of Ditrichopsis see Ignatova \& Afonina (2010).

Variation. Plants from Zabaikalsky Territory differ from Chinese plants (see Ignatova \& Afonina, 2010) in occasional presence of an epidermal cells on adaxial side of costa, while guide cells are exposed in Chinese plants.

Ecology. Two specimens of Ditrichopsis clausa were collected in Sokhondinsky Reserve on a bare soil spots in rocky sedge-Dryas tundra at the top of the mountain. Its scattered shoots were found among Plectocolea hyalina (Lyell) Mitt., Aongstroemia orientalis Mitt., and Campylopus subulatus Schimp. Collections of the species in China and India were also made at a high altitude, at 3550 and $3750 \mathrm{~m}$ a.s.l., respectively. At the same time, D. baicalensis was collected at lower altitudes, 647 $\mathrm{m}$ in Buryatia, 1000-1200 $\mathrm{m}$ in Zabaikalsky Territory and at $30 \mathrm{~m}$ in Krasnoyarsk Territory.

Specimens examined: RUSSIA: Zabaikalsky Territory, Sokhondinsky Nature Reserve, top of Tsagan-Ula Mt. (49³9’42”N, 111²'53”E), 2060 m a.s.1., 19.VIII.2011, Afonina \#4511 (LE); same place and date, Mamontov \#132-2 (LE).
Distribution. Ditrichopsis clausa was described by V.F. Brotherus (1929) from China (Yunnan). It was hitherto known from three localities, in Yunnan \& Sichuan in China (Wu, 1992; Tong \& He, 1999) and in Sikkim, northeast India (Gangulee, 1971). New finding of the species in South Siberia extends its known distribution area to the north and meanwhile adds a new member to the group of East Asian species represented in the moss flora of Zabaikalsky Territory. This group includes Drummondia sinensis Müll. Hal. var. ussuriensis (Broth.) Vitt, Homomallium connexum (Cardot) Broth., Eurohypnum leptothallum (Müll. Hal.) Ando, Leptopterigynandrum incurvatum Broth., Orthodontopsis bardunovii Ignatov \& B.C. Tan, Struckia enervis (Broth.) Ignatov, T.J. Koponen \& D.G. Long, etc.

\section{ACKNOWLEDGEMENTS}

The work was partly supported by RFBR grant \# 1304-01427.

\section{LITERATURE CITED}

[AFONINA, O.M., YU.S. MAMONTOV \& I.V. CZERNYADJEVA] АФОНИНА О.М., Ю.С. МАМОНТОВ, И.В. ЧЕРНЯДЬЕВА 2012. Мхи и печеночники Сохондинского государственного заповедника. - [Mosses and liverworts of the Sokhondinsky State Reserve] Санкт-Петербург [St.-Petersburg]. 200 pp.

BROTHERUS, V.F. 1929. Musci. - Simbolae Sinicae 4: 1-147.

FEDOSOV, V.E. 2012. New moss records from Taimyrsky Municipal Distr. 5. - Arctoa 21: 288-289.

GANGULEE, H.C. 1971. Mosses of Eastern India and adjacent regions. Vol. 1, fasc. 2. - Privately published, Calcutta. 210-566. 
IGNATOVA, E.A. \& O.M. AFONINA 2010. Ditrichopsis baikalensis, a new species from Asiatic Russia. - Arctoa 19: 241-245.

TONG, C. \& SI HE 1999. Ditrichaceae. - In: Li Xing-jiang \& M.R. Cros- by (eds.). Moss Flora of China. Vol. 1: 58-82.

WU, P.-C. 1992. The East Asiatic genera and endemic genera of the bryophytes in China. - Bryobrothera 1: 99-117. 